Ryszard Kamiński

Doktor habilitowany nauk ekonomicznych, profesor, Uniwersytet im. Adama Mickiewicza w Poznaniu, Katedra Nauk Ekonomicznych, ORCID ID 0000-0001-5110-8300

Reasercher ID I-4715-2018

https://doi.org/10.29038/2411-4014-2020-01-87-98 e-mail: $\underline{\text { r_kamin@amu.edu.pl }}$

\title{
RAPORTOWANIE ZAGADNIEŃ Z OBSZARU SPOLECZNEJ ODPOWIEDZIALNOŚCI PRZEDSIĘBIORSTW W ŚWIETLE PRZEPISÓW PRAWA I DOŚWIADCZEŃ PRAKTYCZNYCH
}

Streszczenie. W ostatnich latach w Polsce pojawił się nowy kierunek w systemie raportowania przez przedsiębiorstwa swoich osiągnięć w obszarze społecznej odpowiedzialności przedsiębiorstw. Ramy instytucjonalne tego trendu tworzą nowe przepisy unijne i polskie dotyczące sprawozdawczości niefinansowej przedsiębiorstw. Określają one wyraźny kurs w kierunku większej przejrzystości biznesowej i odpowiedzialności za środowisko. Wdrożenie tych nowych przepisów nastąpiło niedawno. Ta sytuacja stała się inspiracją do przygotowania niniejszego artykułu. Jego celem jest przedstawienie systemu raportowania CSR i skomentowanie go z uwzględnieniem doświadczeń praktycznych. Materiałami wykorzystanymi w artykule są literatura przedmiotu, akty prawne i opublikowane wyniki badania raportowania zagadnień CSR przez przedsiębiorstwa. W artykule uwzględniono regulacje prawne obowiązujące w dniu 31 grudnia $2018 \mathrm{r}$.

Slowa kluczowe: CSR, informacje niefinansowe, standardy raportowania, dyrektywy UE.

Ryszard Kaminski, Doktor hab., profesor, Adam Mickiewicz University in Poznan, Department of Economic Sciences

\section{REPORTING ISSUES IN THE AREA OF CORPORATE SOCIAL RESPONSIBILITY IN THE LIGHT OF LEGAL PROVISIONS AND PRACTICAL EXPERIENCE}

\begin{abstract}
In recent years in Poland there has been a new direction in the system for enterprises to report their achievements in the field of corporate social responsibility tasks. The institutional framework for this trend is provided by new EU and polish regulations referring to non-financial reporting of enterprises. These define a clear course towards more business transparent and environmental responsibility. The implementation of thise new regulations began quite recently. This situation therefore inspired this paper. Its aim is to present the system of CSR reporting and comment on it in terms of the practical experiences. The materials used in the article include subject literature, legal acts and published results of research CSR reporting in practise. The research encompassed legal regulations in force on 31 December 2018.
\end{abstract}

Keywords: CSR, non-financial information, reporting standards, EU directives.

Рішард Камінські, Доктор габілітований економічних наук, професор, Університет ім Адама Міцкевича в Познані, Кафедра економічних наук

\section{ЗВІТНІСТЬ ПРО ПРОБЛЕМИ У СФЕРІ КОРПОРАТИВНОЇ СОЦІАЛЬНОЇ ВІДПОВІДАЛЬНОСТІ 3 ОГЛЯДУ НА ЗАКОНОДАВЧІ ПОЛОЖЕННЯ І ПРАКТИЧНИЙ ДОСВІД}

Анотація. Останніми роками у Польщі з'явився новий напрямок у системі для звітування підприємств про свої досягнення у галузі завдань корпоративного соціального відповідальності. Інституційна база цієї тенденції забезпечується новими правилами СС та Польщі, що стосуються нефінансової звітності підприємств. 
Вони визначають чіткий шлях до більш прозорої та екологічної відповідальності бізнесу. Впровадження нових правил розпочалося зовсім недавно. Тому це сприяло написанню цієї статті. Ї̈̈ мета - представити систему звітності з КСВ та прокоментувати їі з точки зору практичного досвіду. Матеріали, використані у статті, включають тематичну літературу, нормативно-правові акти та опубліковані результати дослідження звітності 3 КСВ на практиці. Дослідження охопило законодавчі норми, що діють 31 грудня 2018 року.

Ключові слова: КСВ, нефінансова інформація, стандарти звітності, директиви ЄС.

Wstęp. Współcześnie rośnie zainteresowanie społecznymi i środowiskowymi aspektami prowadzenia działalności przez przedsiębiorstwa. Coraz częściej interesariusze przedsiębiorstw oczekują, że przedsiębiorstwa będą dostarczały im raportów potwierdzających, iż ich działalność jest społecznie odpowiedzialna. Tradycyjne sprawozdania finansowe nie są w stanie w sposób kompletny i wierny ukazać całościowego obrazu działalności przedsiębiorstwa, z uwzględnieniem jego wpływu na otoczenie, w tym dostarczyć informacji o sposobach i wynikach realizacji koncepcji społecznej odpowiedzialności przedsiębiorstw (ang. corporate social responsibility - CSR). To sprawiło, że zakres przedmiotowy dotychczasowej sprawozdawczości przedsiębiorstw został poszerzony o aspekty środowiskowe, społeczne i ładu korporacyjnego.

Ramami instytucjonalnymi tego nowego kierunku rozwoju sprawozdawczości przedsiębiorstw są przepisy dotyczące sprawozdawczości niefinansowej. W Polsce tego rodzaju sprawozdawczość została ukształtowana przede wszystkim przez regulacje Unii Europejskiej, w szczególności na skutek wprowadzenia dyrektyw dotyczących ujawniania informacji niefinansowych i informacji dotyczących różnorodności przez niektóre duże przedsiębiorstwa i grupy. Regulacje te wskazały wyraźny kurs na rzecz większej przejrzystości biznesowej i odpowiedzialności w kwestiach społecznych i środowiskowych.

Wdrożenie do praktyki nowych regulacji dotyczących raportowania kwestii z obszaru społecznej odpowiedzialności nastąpiło niedawno, bo w 2017 r. Sytuacja ta stała się więc inspiracją do przygotowania niniejszego artykułu. Jego celem jest prezentacja i ocena systemu raportowania kwestii CSR mając na względzie doświadczenia praktyczne. W pierwszej części opracowania została przedstawiona istota społecznej odpowiedzialności biznesu. Następnie dokonano przeglądu koncepcji i standardów raportowania zagadnień CSR, by potem skupić się na omówieniu i ocenie przepisów prawnych obowiązujących w UE i w Polsce oraz praktyki polskich przedsiębiorstw w tym zakresie.

Materiałami wykorzystanymi w artykule są: literatura przedmiotu, akty prawne, oraz opublikowane wyniki badań nad raportowaniem niefinansowym w Polsce. Wykorzystano przede wszystkim raport na temat ujawniania informacji niefinansowych opublikowany przez Ministerstwo Finansów, które zbadało praktykę przedsiębiorstw w tym zakresie w Polsce. Materiałem uzupełniającym były również wyniki analiz przeprowadzonych przez innych badaczy. W toku rozważań zastosowano przede wszystkim metodę krytycznej analizy źródeł literaturowych i aktów prawnych oraz metodę porównawczą. Uwzględniono stan prawny na dzień 31 grudnia $2018 \mathrm{r}$.

Istota społecznej odpowiedzialności przedsiębiorstw. Koncepcja społecznej odpowiedzialności przedsiębiorstw narodziła się pod koniec XIX wieku w USA [1] i w XX wieku rozprzestrzeniła się w Europie. Koncepcja ta wyrosła $\mathrm{z}$ rozważań prowadzonych na gruncie stakeholders theory. Współczesne postrzeganie koncepcji społecznej odpowiedzialność przedsiębiorstw narodziło sięw drugiej połowie XX wieku. Zapoczątkowała je publikacja H. R. Bowena Social Responsibilities of the Busi-nessman [2]. Była ona pierwszą, kompleksową i - jak się potem okazało - przełomową pracą na temat etyki biznesu i odpowiedzialności społecznej. Idea społecznej odpowiedzialności przedsiębiorstw została upowszechniona pod koniec lat pięćdziesiątych i sześćdziesiątych XX wieku wraz z ekspansją wielkich korporacji. Stała się popularnym tematem rozważań teoretyków i praktyków w latach osiemdziesiątych $\mathrm{XX}$ wieku w związku z rozwojem teorii zarządzania strategicznego. Wzmożone zainteresowanie koncepcją CSR nastąpiło w następstwie kryzysu finansowego w latach 2007-2010.

Społeczna odpowiedzialność przedsiębiorstw jest różnie nazywana i definiowana. W literaturze przedmiotu najczęściej używa się komplementarnych względem siebie określeń społecznej odpowiedzialności, takich jak: Corporate Social Responsibility (CSR), Corporate Responsibility (CR), Business Responsibility, Corporate Sustainability, Corporate Citizenship (CC), Global Business Citizenship czy też Corporate Community Engagement. W Polsce natomiast stosuje się m.in. takie terminy, jak 
społeczna odpowiedzialność przedsiębiorstw, społeczna odpowiedzialność biznesu czy też odpowiedzialność przedsiębiorstwa.

$\mathrm{Na}$ początku przyjmowano, iż ideą społecznej odpowiedzialności przedsiębiorstw jest dobrowolne, wykraczające poza minimalne wymogi prawne, uwzględnianie przez przedsiębiorstwa $\mathrm{w}$ przyjętej przez siebie strategii działania oraz w stosunkach z zainteresowanymi stronami - interesów społecznych, potrzeb różnych grup interesariuszy oraz poszanowania środowiska przyrodniczego. Przykładem takiego rozumienia omawianej idei jest sformułowanie J. Surdyka, dla którego jest nią „(...) zbiór zobowiazań $i$ praktyk biznesowych, mieszczacych się w spektrum dziatań gdzieś pomiędzy tradycyjna dobroczynnościa a ścistym przestrzeganiem prawa"[3]. Społeczną odpowiedzialność biznesu powszechnie zwykło traktować się jako strategię zarządzania, która poprzez prowadzenie dialogu społecznego na poziomie lokalnym przyczynia się do wzrostu konkurencyjności przedsiębiorstw na poziomie globalnym i jednocześnie sprzyja poprawie relacji $\mathrm{z}$ różnymi grupami interesariuszy oraz zrównoważonemu rozwojowi społecznemu i ekonomicznemu[4]. W swoich pracach stanowisko takie prezentują m.in. P. Drucker[5] czy też M. Porter i M. Kramer[6]. W kontekście zakresów odpowiedzialności przedsiębiorstwa za wpływ na otoczenie, przywołuje się również koncepcję ewidencji i sprawozdawczości osiągnięć przedsiębiorstwa autorstwa J. Elkingtona - Triple-bottom-line (TBL), w której uwzględnia się jego powiązania w otoczeniem w sferze ekonomicznej, społecznej i środowiskowej[7].

Współczesne postrzeganie społecznej odpowiedzialności przedsiębiorstwa jest powiązane z koncepcją zrównoważonego i trwałego rozwoju. Koncepcja ta została zdefiniowana w 1987 r. w Raporcie Brundtland Światowej Komisji do Spraw Środowiska i Rozwoju gdzie zrównoważony i trwały rozwój rozumiany jest jako proces zmian, w którym eksploatacja zasobów umożliwia zaspokajanie aktualnych potrzeb i daje także możliwość rozwoju przyszłym pokoleniom[8]. Koncepcja zrównoważonego i trwałego rozwoju zakłada nieprzerwany wzrost gospodarczy w celu zaspokojenia ludzkich potrzeb i aspiracji oraz podnoszenia jakości życia w warunkach poszanowania zasobów naturalnych i walorów środowiskowych.

Idea społecznej odpowiedzialności przedsiębiorstw stała się przedmiotem zainteresowania Unii Europejskiej. Potwierdza to fakt przyjęcia w 2011 roku przez Komisję Europejską definicji CSR, w której znalazło się stwierdzenie, iż (...) przedsiębiorstwa powinny dysponować mechanizmem integracji kwestii społecznych, środowiskowych, etycznych $i$ tych zwiazanych $z$ prawami czlowieka, jak $i$ problemów konsumentów ze swoja działalnościa oraz podstawowa strategia, w ścistej wspótpracy $z$ zainteresowanymi stronami[9]. Spowodowało, to wiele działań z zakresu CSR postrzeganych jest jako obligatoryjne ze względu na fakt, że wszystkie organizacje gospodarcze generują różnorodne wpływy społeczne czy środowiskowe. Zadania z obszaru społecznej odpowiedzialności przedsiębiorstw traktowane są jako zobowiązania przez Światową Radę Biznesu na rzecz Zrównoważonego Rozwoju, która rozumie odpowiedzialność społeczną przedsiębiorstw jako „ciagłe zobowiąanie biznesu do zachowania etycznego oraz przyczyniania się do zrównoważonego rozwoju ekonomicznego poprzez poprawe jakości życia pracowników i ich rodzin, jak również lokalnej społeczności i społeczeństwa jako całości”[10].

Należy zauważyć, że w ujęciu Światowej Rady Biznesu działalność przedsiębiorstwa, która z natury rzeczy ma przynieść zysk, ma również tworzyć szeroko rozumiane korzyści zarówno dla jego odbiorców i ogółu społeczeństwa. Jest to wyraz holistycznego i altruistycznego ${ }^{1}$ podejścia do biznesu, którego działalność postrzegana jest jako źródło rozwoju i postępu społecznego. U podstaw takiego podejścia leży fakt, że każde przedsiębiorstwo (nawet prywatne) jest organem społeczeństwa i spełnia określoną funkcję społeczną. Myśl ta znajduje niekiedy zakorzenienie historyczne. $\mathrm{Na}$ przykład w tradycyjnych społeczeństwach afrykańskich, przedsiębiorstwa były postrzegane przede wszystkim jako organizacje zapewniające korzyści dla całego społeczeństwa, zaś korzyści osiągane przez przedsiębiorcę były traktowane drugorzędne[11].

\footnotetext{
${ }^{1}$ Zgodnie z międzynarodową normą ISO26000 do dobrych praktyk CSR zalicza się filantropijne ,zaangażowanie i rozwój społeczności lokalnej”. Niemniej filantropia to tylko niewielki element działań z obszaru społecznej odpowiedzialności biznesu. Według wytycznych ISO CSR obejmuje ponadto praktyki dotyczące ładu organizacyjnego, praw człowieka, bhp, środowiska, uczciwych praktyk rynkowych. Takie szerokie ujęcie pozwala odróżnić jednorazowe, działania dobroczynne motywowane często jedynie korzyściami wizerunkowymi od pozostałych działań świadczących o odpowiedzialnym podejściu do biznesu.
} 
Panuje przekonanie, że działając w zgodzie z zasadami CSR przedsiębiorstwa mogą uzyskać wiele korzyści. Wśród nich wymienia się najczęściej:

1. Wzrost zainteresowania inwestorów, którzy zwracają uwagę nie tylko na uzyskiwane wyniki finansowe, ale i na jakość zarządzania; dla inwestorów coraz częściej wiarygodność finansowa przedsiębiorstwa powiązana jest $\mathrm{z}$ jej wiarygodnością społeczną; (istotne jest dla nich nie tylko jak przedsiębiorstwo dzieli się swoim zyskiem, ale w jaki sposób go osiąga, czy nie dzieje się to kosztem pracowników, środowiska naturalnego, klientów).

2. Zwiększenie lojalności konsumentów i interesariuszy, którzy w swoich wyborach kierują się m.in. zaufaniem do danego podmiotu; to z kolei wzrasta gdy przedsiębiorstwo przestrzega zasad społecznej odpowiedzialności biznesu.

3. Poprawa relacji ze społecznością i władzami lokalnymi.

4. Wzrost przewagi konkurencyjnej szczególnie na rozwiniętych rynkach zagranicznych, gdzie oczekiwania dotyczące spełniania standardów odpowiedzialnego biznesu są coraz bardziej powszechne.

5. Kształtowanie pozytywnego wizerunku przedsiębiorstwa wśród pracowników, co jest ważnym elementem niematerialnego systemu motywowania pracowników; (prospołeczna działalność przedsiębiorstwa, kierowanie się zasadami etycznymi, dbałości o środowisko poprawia wizerunek firmy w oczach pracowników)[12] [13].

W literaturze przedmiotu można również spotkać sceptyczne opinie na co do faktycznych wartości niesionych przez teorię i praktykę CSR. Autorzy poddający w wątpliwość sens tej idei twierdzą, że działalność w obszarze CSR odrywa przedsiębiorstwa od ich fundamentalnej funkcji ekonomicznej jakim jest „zarabianie”, a inni dopowiadają, że działalność ta to nic więcej niż powierzchowne "window dressing". Uważają oni bowiem, że zachowania tzw. społecznie odpowiedzialne nie są prawdziwym zamiarem przedsiębiorstw. Realizowane przez nie programy CSR są - według nich - jedynie wypełnieniem obowiązków regulacyjnych nałożonych przez władzę gospodarczą. Zatem krytycy idei CSR w konkluzji stwierdzają, że zarządy korporacji nie tyle są odpowiedzialni wobec społeczeństwa, co dążą do uniknięcia konsekwencji wynikających z braku tej odpowiedzialności[14].

Standardy i uregulowania prawne sprawozdawczości z zakresu CSR. Idea ujawniania informacji na temat odpowiedzialności przedsiębiorstwa przed społeczeństwem została sformułowana już w $1973 \mathrm{r}$. przez American Institute of Certified Public Accountants w opracowaniu zatytułowanym "Objectives of Financial Statements", w którym określono podstawowe cele sprawozdawczości finansowej. Wśród nich wymienia się ,informowanie o działaniach przedsiębiorstwa mających wplyw na spoleczeństwo, które moga być określone $i$ opisane lub zmierzone, $i$ które sa ważne ze względu na role jaka przedsiębiorstwo odgrywa w środowisku spolecznym"[15].

Z myślą o podniesieniu jakości i zwiększeniu porównywalności sprawozdań dotyczących społecznej odpowiedzialności przedsiębiorstw już $\mathrm{w}$ latach siedemdziesiątych $\mathrm{XX}$ w. zapoczątkowano prace nakierowane na opracowanie i wdrożenie do praktyki standardów raportowania zagadnień $z$ tego obszaru. Jak do tej pory nie wypracowano jednak ujednoliconych i powszechnie akceptowanych standardów sprawozdawczości zagadnień społecznych. To sprawia, że w praktyce stosowane są różne normy, zalecenia i wytyczne. Przedsiębiorstwa mogą więc bazować na różnych propozycjach sprawozdawczości CSR wypracowanych przez wiele organizacji. Wśród nich znajdują się opracowania następujących organizacji:

- United Nations Global Compact (UNGC),

- Organizacji Współpracy Gospodarczej i Rozwoju (OECD),

- Międzynarodowej Organizacji Pracy (ILO),

- Global Reporting Initiative (GRI),

- AccountAbility,

- Międzynarodowej Organizacji Normalizującej (ISO).

Wdrożenie do praktyki przedsiębiorstw idei społecznej odpowiedzialności stało się również celem Unii Europejskiej. Znalazło to wyraz w opublikowanej przez Komisję Europejską w 2001 r. Zielonej Księdze CSR[16] oraz w 2002 r. Białej Księdze CSR[17]. W tym ostatnim dokumencie wskazano pożądane działania z zakresu CSR. Uznano, że powinny być nimi: edukacja, wymiana doświadczeń i dobrych praktyk, rozwój instrumentów społecznej odpowiedzialności biznesu, uruchomienie Europejskiego Forum Interesariuszy oraz włączanie problematyki CSR do wszystkich polityk UE (zatrudnienia, gospodarczej, środowiskowej, konsumenckiej, zewnętrznej, w instytucjach administracji publicznej). 
Bardzo ważnym etapem w procesie tworzenia systemu raportowania zagadnień z obszaru CSR było uchwalenie Dyrektywy 2013/34/UE[18], która przewiduje ujawnianie informacji dotyczących kwestii środowiska naturalnego, kwestii społecznych i pracowniczych, w tym ochrony praw człowieka, przeciwdziałaniu nadużyciom i korupcji, przestrzeganiu zasady różnorodności kadry zarządzającej. Dyrektywa 2013/34/UE zobowiązała do ujawniania informacji związanych ze społeczną odpowiedzialnością biznesu duże przedsiębiorstwa interesu publicznego, które mają więcej niż 500 pracowników.

Następnym milowym krokiem na drodze doskonalenia systemu raportowania zagadnień CSR było przyjęcie w 2014 r. Dyrektywy Parlamentu Europejskiego i Rady 2014/95/UE zmieniającą dyrektywę 2013/34/UE w odniesieniu do ujawniania informacji niefinansowych i informacji dotyczących różnorodności przez niektóre duże jednostki oraz grupy[19]. Dyrektywa 2014/95/UE określiła tematykę obowiązkowych raportów niefinansowych. Uznano, że powinny one zawierać:

- w odniesieniu do kwestii środowiskowych: informacje na temat obecnego i przewidywanego wpływu działalności jednostki na środowisko oraz, na zdrowie i bezpieczeństwo, wykorzystywanie energii odnawialnej lub nieodnawialnej, emisję gazów cieplarnianych, zużycie wody i zanieczyszczenie powietrza;

- w odniesieniu do spraw społecznych i pracowniczych; informacje na temat działań podejmowanych w celu zapewnienia równouprawnienia płci, wdrożenia podstawowych konwencji Międzynarodowej Organizacji Pracy, warunków pracy, dialogu społecznego, poszanowania prawa pracowników do informacji i do wyrażania opinii, poszanowania praw związków zawodowych, bezpieczeństwa i higieny pracy oraz dialogu ze społecznościami lokalnymi lub działań podejmowanych w celu zapewnienia ochrony i rozwoju tych społeczności;

- w odniesieniu do praw człowieka oraz walki z korupcją i łapownictwem: oświadczenie na temat zapobiegania naruszaniu praw człowieka lub na temat stosowanych instrumentów walki z korupcją $\mathrm{i}$ łapownictwem.

Wytyczne sporządzania sprawozdań na temat CSR, które uznane jako wartościowe w Odnowionej strategii UE na lata 2011-2014 [20] ( tj. standardy UN Global Compact, wytyczne Organizacji Współpracy Gospodarczej i Rozwoju, normę ISO 26000 oraz Trójstronną deklarację Międzynarodowej Organizacji Pracy) uzupełniono jeszcze o krajowe zasady ramowe oraz unijne zasady ramowe tj. System Ekozarządzania i Audytu (EMAS) [21]. W celu wsparcia przedsiębiorstw w przygotowaniu sprawozdań niefinansowych Komisja Europejska w 2017 r. opublikowała wytyczne do dyrektywy 2014/95/UE [22]. Wytyczne uwzględniają postanowienia porozumienia klimatycznego ONZ COP podpisane w Paryżu w 2015 r., zobowiązujące do ujawniania informacji na temat rzeczywistego i potencjalnego wpływu działań organizacji na środowisko, zwłaszcza w odniesieniu do redukcji emisji gazów cieplarnianych[23]. Nowe przepisy unijne po raz pierwszy zastosowano w praktyce w $2017 \mathrm{r}$.

W Polsce obowiązek publikowania danych $\mathrm{z}$ obszaru CSR wynika z przepisów ustawy o rachunkowości[24] dotyczących sprawozdania $\mathrm{z}$ działalności. $\mathrm{W}$ art. 49 pkt. 3 tego aktu prawnego stwierdza się, iż „Sprawozdanie z działalności jednostki powinno również obejmować - o ile jest to istotne dla oceny sytuacji jednostki - wskaźniki finansowe i niefinansowe, tacznie z informacjami dotyczacymi zagadnień środowiska naturalnego i zatrudnienia, a także dodatkowe wyjaśnienia do kwot wykazanych $w$ sprawozdaniu finansowym". Ponadto w związku z obowiązkiem wdrożenia przez państwa członkowskie UE postanowień dyrektywy 2014/95/UE do polskiego prawa o rachunkowości wprowadzono nowy przepis. Jest nim art. $49 \mathrm{~b}$ ustawy o rachunkowości ${ }^{1}$. W świetle tego przepisu informacje niefinansowe, w tym dotyczące kwestii z obszaru CSR, podlegają obowiązkowi sprawozdawczemu. Obowiązek ten dotyczy przedsiębiorstw, które w roku obrotowym, za który sporządzają sprawozdania finansowe, oraz w roku poprzedzającym ten rok przekroczyły następujące kwoty:

1. 500 osób - w przypadku średniego rocznego zatrudnienia w przeliczeniu na pełny etat,

2. $85000000 \mathrm{zl}-\mathrm{w}$ przypadku sumy aktywów bilansowych na koniec roku obrotowego lub

3. $170000000 \mathrm{zl}-\mathrm{w}$ przypadku przychodów netto ze sprzedaży towarów i produktów za rok obrotowy.

Zestaw ujawnianych informacji obejmuje co najmniej:

\footnotetext{
${ }^{1}$ Należy dodać, że kwestia informacji o stosowaniu zasad ładu korporacyjnego jest również przedmiotem Krajowego Standardu Rachunkowości nr 9 [25].
} 
1. zwięzły opis modelu biznesowego jednostki;

2. kluczowe wskaźniki wyników niefinansowych związanych z działalnością jednostki;

3. opis zasad stosowanych przez jednostkę w odniesieniu do kwestii społecznych, zatrudnienia, ochrony środowiska, poszanowania praw człowieka i przeciwdziałania korupcji, a także opis wyników stosowania tych polityk;

4. opis procedur należytej staranności;

5. opis istotnych rodzajów ryzyka związanych z działalnością jednostki, które mogą mieć negatywny wpływ na kwestie, o których mowa w pkt 3, w tym rodzajów ryzyka związanych z produktami jednostki lub jej relacjami ze środowiskiem zewnętrznym, w tym kontrahentami, a także opis zarządzania tymi rodzajami ryzyka.

Sporządzając tego rodzaju raporty przedsiębiorstwa mogą stosować wszelkie zasady, w tym zasady własne, standardy krajowe, unijne lub międzynarodowe. Wśród tych standardów znajduje się opracowany w 2017 r. polski Standard Informacji Niefinansowych (SIN) [26]. Standard ten został dedykowany przede wszystkim przedsiębiorstwom, które wcześniej nie sporządzały raportów CSR.

Wśród treści wymaganych w sprawozdaniu niefinansowym gro informacji dotyczy obszaru CSR. Są to informacje odnoszące się do:

1. Kwestii środowiskowych, w szczególności na temat:

- teraźniejszego i przyszłego wpływu na środowisko;

- poziomu wykorzystywania energii nieodnawialnej i odnawialnej;

- poziomu emisji gazów cieplarnianych,

- zanieczyszczenia powietrza i zużycia wody.

2. Kwestii społecznych i pracowniczych, w tym:

- działań podejmowane na rzecz równouprawnienia płci, godnych warunków pracy, dialogu społecznego;

- poszanowania praw związków zawodowych;

- działań w zakresie zapewnienia bezpieczeństwa i higieny pracy;

- działań w zakresie zapewnienia prawa do wyrażania opinii przez pracowników, prawa do informacji oraz innych praw pracowników;

- podejmowania dialogu ze społecznościami i zapewnienie im rozwoju i ochrony;

3. Kwestii związanych z prawami człowieka, a w szczególności działań na rzecz zapobiegania łamania i naruszania praw człowieka;

4. Kwestii związanych z przeciwdziałaniem korupcji i łapownictwu, a w szczególności instrumentów i narzędzi zastosowanych do walki $\mathrm{z}$ łapownictwem i korupcją.

Praktyka raportowania zagadnień CSR. Praktyka sporządzania sprawozdań dotyczących zagadnień CSR wywołała potrzebę zdefiniowania pojęcia rachunkowości oraz sprawozdawczości odpowiedzialności społecznej. Według T. Gabrusewicza rachunkowość odpowiedzialności społecznej jest to rachunkowość uwzględniająca obciązenia i korzyści dla społeczeństwa wynikające z działalności konkretnego podmiotu gospodarujacego przedstawione $w$ formie wartościowej lub opisowej[27]. Produktem końcowym tego rodzaju rachunkowości jest raport społecznej odpowiedzialności przedsiębiorstw. Jego zadaniem - jak stwierdza P. Hąbek - jest dostarczanie informacji zarówno dla interesariuszy wewnątrz firmy, jak i tych zewnętrznych, na temat wyników osiąganych przez jednostkę gospodarczą w aspekcie społecznym, środowiskowym i ekonomicznym[28].

W praktyce raporty zagadnień CSR sporządzane są w różny sposób. Wśród nich można wyodrębnić następujące formy, a mianowicie:

1. Rozszerzenie raportu rocznego; przedsiębiorstwo w sprawozdaniu finansowym w dodatkowej części prezentuje swoją działania dotyczące społecznej odpowiedzialności.

2. Przygotowanie osobnego raportu zrównoważonego rozwoju jako uzupełnienie rocznego sprawozdania finansowego; oprócz sprawozdania finansowania, przedsiębiorstwo sporządza odrębny raport, którego treścią są rezultaty działań nie tylko w obszarze ekonomicznym, ale i obszarach społecznym i środowiskowym.

3. Przygotowanie kilku osobnych raportów; każdy z nich dotyczy różnych aspektów związanych ze zrównoważonego rozwojem przedsiębiorstwa (np. raport społeczny, raport środowiskowy itp.). 
4. Sporządzenie raportu zintegrowanego; przedsiębiorstwo przygotowuje jeden raport, który zawiera zarówno dane finansowe, jak i niefinansowe oraz prezentuje ich wzajemne powiązania i zależności[28].

W Polsce pierwsze raporty niefinansowe, w tym obejmujące kwestie CSR, sporządzone zgodnie z wymogami ustawy o rachunkowości oraz Dyrektywy 2014/95/UE powstały w 2018 roku i objęly rok 2017. W 2019 roku ukazał się raport Ministerstwa Finansów dotyczący praktyki ujawniania informacji niefinansowych pt. Raportowanie rozszerzonych informacji niefinansowych za 2017 rok zgodnie z ustawa o rachunkowości - pierwsze doświadczenia $i$ dobre praktyki[29]. Celem autorów raportu była analiza raportów sporządzonych obowiązkowo za rok sprawozdawczy 2017. Raport powstał w oparciu o analizę 123 sprawozdań niefinansowych sporządzonych przez 100 spółek (w tym 98 spółek notowanych na GPW i 2 banków nienotowanych) reprezentujących 8 sektorów: finanse, paliwa i energia, chemia i surowce, produkcja przemysłowa i budowlano-montażowa, dobra konsumpcyjne, handel i usługi, ochrona zdrowia oraz technologie ${ }^{1}$. Poniża relacja $\mathrm{z}$ badań ekspertów Ministerstwa Finansów koncentruje się na najważniejszych zagadnieniach mieszczących się w zakresie przedmiotowym CSR. W raporcie MF zostały one ukazane w podpunktach dotyczących:

- formy prezentacji informacji niefinansowych,

- opisu polityk w obszarach społecznym, pracowniczym, środowiska naturalnego, poszanowania praw człowieka oraz przeciwdziałania korupcji,

- opisu rezultatów stosowanych polityk,

- informacji o zastosowanych standardach i zasadach wykorzystanych przy sporządzaniu raportu.

Badane sprawozdania spółek polskich w 73 przypadkach (tj. w prawie $60 \%$ ogółu) stanowiły odrębne sprawozdania. Reszta tj. 50 sprawozdań miało formę odrębnych oświadczeń w ramach sprawozdań z działalności. Okazuje się zatem, że badane jednostki chętnie skorzystały z możliwości sporządzenia odrębnego sprawozdania, która była możliwa dzięki skorzystaniu przez Polskę $\mathrm{z}$ opcji zawartej $\mathrm{w}$ Dyrektywie 2014/95/UE. Eksperci MF zauważyli, że jednostki dość swobodnie podeszły do terminologii zastosowanej $\mathrm{W}$ ustawie o rachunkowości, zgodnie $\mathrm{z}$ którą oświadczenie na temat informacji niefinansowych sporządza się ,jako wyodrębnioną część” $\mathrm{w}$ ramach sprawozdania $\mathrm{z}$ działalności, a alternatywą jest sporządzenie odrębnego sprawozdania na temat informacji niefinansowych.

Jeśli chodzi o przedstawienie opisu polityk w obszarach społecznym, pracowniczym, środowiska naturalnego, poszanowania praw człowieka oraz przeciwdziałania korupcji to zarówno unijne jak i polskie regulacje nie narzuciły wymogu prowadzenia przez przedsiębiorstwo polityki we wskazanych obszarach, a jedynie wymóg jej ujawnienia, jeśli jednostka taką politykę prowadzi. Zatem celem ekspertów MF było jedynie zbadanie czy wymóg ten jest respektowany. Okazało się, że opis polityki w obszarze społecznym był przedstawiony w 89 raportach, natomiast w 27 (tj. $23 \%$ ogółu badanych raportów w tym zakresie) opisu tego nie było, z tego w 17 przypadkach nie przedstawiono wyjaśnienia braku prowadzenia tej polityki. W przypadku obszaru pracowniczego kwoty te przedstawiały się odpowiednio: 105, $11 \mathrm{i} 5$. W przypadku obszaru środowiska naturalnego: 100, 16 i 6 . Z kolei w przypadku obszaru poszanowania praw człowieka kwoty te wynosiły: 90, 26 i 11 . Natomiast w przypadku obszaru przeciwdziałania korupcji proporcje te kształtowały się: 102, 14 i 5.

Przedstawione dane potwierdzają, ze wymóg opisu polityki jednostki w danym obszarze w większości przypadków został wypełniony. Najwyższe wskaźniki odnotowano w obszarze pracowniczym, najgorsze w obszarach: społecznym oraz praw człowieka. W opinii ekspertów najwięcej trudności w raportowaniu sprawiły badanym jednostkom zagadnienia dotyczące ochrony praw człowieka.

Co się tyczy opisu rezultatów stosowanych polityk to przepisy ustawy o rachunkowości obligują do zawarcia $\mathrm{w}$ raporcie niefinansowym opisu rezultatów stosowanych polityk w obszarach określonych w art. 49b ust. 2. Badania MF dowodzą, że opis taki w obszarze społecznym przedstawiony został w 84 sprawozdaniach niefinansowych, (tj. $72 \%$ badanych raportów). W przypadku obszaru pracowniczego raportów tych było 98 (tj. $84 \%$ ). W przypadku obszaru środowiska naturalnego - 91 (tj. 78\%). (Raportowanie rezultatów polityki w zakresie ochrony środowiska należy ocenić pozytywnie; nie budzi to wszakże zdziwienia bowiem w tym zakresie istnieją sprawdzone w praktyce efektywne procedury). W

\footnotetext{
${ }^{1}$ Szacuje się, że w Polsce obowiązek przygotowania raportu o kwestiach niefinansowych został nałożony na ok. 300 organizacji biznesowych. Stąd wyniki badań MF, którymi objęto 30 \% ogólnej liczby tych podmiotów można uznać za reprezentatywne.
} 
przypadku obszaru poszanowania praw człowieka raportów tych było - 66 (tj. 57\%) i w przypadku obszaru przeciwdziałania korupcji - 80 (tj. 69\%). Jak widać, podobnie jak w przypadku opisu prowadzonych polityk, opis rezultatów tych polityk najlepiej wypada w obszarze pracowniczym, a najsłabiej w obszarze praw człowieka, w którym w $43 \%$ przypadków nie podano informacji o rezultatach tej polityki; (eksperci zaznaczyli, że nie było nawet lakonicznej informacji o braku przypadków np. dyskryminacji, mobbingu, pracy przymusowej czy pracy nieletnich). Zgodzić się zatem należy z ich wnioskiem, że zagadnienia $\mathrm{z}$ obszaru praw człowieka najbardziej wymagają podniesienia poziomu jakości w raportowaniu informacji niefinansowych.

Przepisy ustawy o rachunkowości nakazują podanie informacji na temat standardów lub zasad z jakich przedsiębiorstwo skorzystało przy sporządzaniu raportu. Badania ekspertów MF potwierdziły, iż w 109 sprawozdaniach polskich spółek przedstawiono taką informację. Reszta tj. sprawozdania 7 spółek nie zawierały danych o tym, z jakich standardów lub zasad spółka skorzystała przy sporządzaniu raportu niefinansowego, a nawet nie zawierały wzmianki, że zastosowano własne zasady. Najczęściej wykorzystywano standardy GRI w wersji G.4. Uczyniono to w przypadku 47 sprawozdań. Natomiast 25 raportów bazowało na polskim Standardzie Informacji Niefinansowych. Własne zasady zastosowano w przypadku 24 raportów, które w większości przypadków były inspirowane standardami GRI, SIN czy też Wytycznymi KE. Z kolei 5 spółek podało, że skorzystało z innych wytycznych (m.in. norm ISO 26000, suplementów sektorowych GRI G4 w zakresie odnoszącym się do górnictwa).

Charakterystyczne jest to, że badane jednostki nie wskazały, iż wykorzystywały do sporządzenia raportów Wytyczne KE. Zapewne nie bez wpływu na taką sytuację miało to, że Wytyczne te ukazały się dopiero w 2017 r, a ponadto ich dość ogólna treść w porównaniu z innymi standardami zawierającymi wykaz praktycznych wskaźników czy też procedur.

Raport ekspertów MF zawiera również informację na temat badania sprawozdań niefinansowych badanych spółek. Okazało się, że informacja na ten temat była zawarta jedynie w 9 sprawozdaniach, przy czym audyt zewnętrzny był prowadzony jedynie w 3 przypadkach.

Raportowanie informacji niefinansowych, w tym zagadnień z obszaru społecznej odpowiedzialności przedsiębiorstw było również przedmiotem badań J. Rubik[30]. Przeprowadziła ona badanie raportów niefinansowych (ujmujących również kwestie CSR) spółek giełdowych objętych projektem Respect Index ${ }^{1}$. Badaniu poddano 27 spółek wchodzących w skład Respect Index od 2016 r. , i które przygotowały raporty finansowe za 2017 r. Autorka badania rozpatrzyła następujące kwestie: formę prezentacji danych niefinansowych, rodzaj wykorzystanych standardów sporządzania raportów niefinansowych oraz kwestię weryfikacji raportowanych danych niefinansowych.

Badania potwierdziły, że 14 spółek dane niefinansowe zamieściło w sprawozdaniu z działalności. Natomiast 13 spółek sporządziło odrębne oświadczenie na temat danych niefinansowych nazywane niekiedy raportem odpowiedzialności społecznej. Jedna spółka sporządziła obszerne oświadczenie zawierające dane niefinansowe w sprawozdaniu z działalności oraz odrębny raport zrównoważonego rozwoju.

Co do wykorzystanych standardów raportowania niefinansowego to okazało się, że 21 spółek bazowało na formacie GRI G4 w jego podstawowej wersji Core. Pięć spółek skorzystało ze standardów sektorowych. Pięć innych spółek zastosowało normy Global Copact oraz ISO 26000. Jedynie 4 spółki bazowały na polskim standardzie SIN. Natomiast 4 spółki nie podały norm czy wytycznych, które wykorzystały przy sporządzaniu raportów ${ }^{2}$.

\footnotetext{
${ }^{1}$ Respekt Index obejmuje spółki notowane na Giełdzie Papierów Wartościowych w Warszawie uznane za społecznie odpowiedzialne. Są to spółki o najwyższej płynności wchodzące w skład indeksów WIG20, mWIG40, sWIG80. ${ }^{2}$ Popularność standardów GRI wśród spółek giełdowych w Polsce została również potwierdzona w raporcie przygotowanym przez firmę NavigatorCapital. Zbadała ona raporty niefinansowe sporządzone przez spółki notowane na GPW. Okazało się, że spośród 51 badanych jednostek 27 spółek raporty sporządziły na podstawie Global Reporting Initiative. Dwanaście spółek wskazało, iż sprawozdanie niefinansowe zostało sporządzone w oparciu o własne zasady uwzględniające przepisy ustawy o rachunkowości, wytyczne Komisji Europejskiej, dotyczące sprawozdawczości w zakresie informacji niefinansowych oraz standardy polskie (SIN) i międzynarodowe (GRI). Także dwanaście spółek w swoich raportach w ogóle nie wskazało na podstawie jakich wytycznych zostały przygotowane informacje niefinansowe [31].
} 
Jeśli chodzi o audyt sporządzonych raportów niefinansowych to tylko 4 spółki podały, iż poddały je badaniu przez firmę zewnętrzną. Cztery inne wyraźnie oświadczyły, że tego nie uczyniły. Pozostałe spółki nie wypowiedziały się w tej kwestii.

Badania sprawozdań zawierających dane niefinansowe były przeprowadzane przed wprowadzeniem obowiązku ich raportowania. Warto przytoczyć wyniki badania wykonanego na krótko przed wprowadzeniem tego obowiązku przez A. Piotrowską[32]. Zbadała ona raporty niefinansowe czterech największych polskich spółek z sektora energetycznego, tj. Polskiej Grupy Energetycznej S.A., Tauron Polska Energia S.A., Enea S.A. oraz Energa S.A. sporządzone za 2015 r. Osobną uwagę zwróciła na informacje dotyczące społecznej odpowiedzialności przedsiębiorstw. W szczególności rozpoznała następujące kwestie: rodzaj wykorzystanych standardów do raportowania CSR, zawartość raportów niefinansowych, przeprowadzanie audytu raportów CSR oraz ich mocne i słabe strony.

Okazało się, że wszystkie spółki skorzystały ze standardów GRI G4 Raportowanie odpowiedzialnego biznesu i zrównoważonego rozwoju, w tym trzy spółki w jego opcji Core. Jedna spółka wykorzystała ponadto standard IIRC. Te spółki, które bazowały jedynie na standardach GRI G4 sporządziły osobne raporty CSR. Natomiast spółka bazująca także na standardach IIRC kwestię CSR ukazała w raporcie zintegrowanym. Zawartość raportów wszystkich spółek była podobna. Prezentowały one:

- swoją misję, wizję i strategię,

- otoczenie rynkowe (w tym łańcuch dostaw oraz relacje z interesariuszami),

- kapitały (produkcyjny, ludzki, naturalny i w przypadku sprawozdania zintegrowanego - kapitał finansowy).

Jeśli chodzi o weryfikację treści zawartych w sprawozdaniach to - jak się okazało - tylko dwa raporty były badane przez zewnętrznych audytorów, a w jednym przypadku było to badanie wewnętrzne.

Do mocnych stron prezentowanych raportów autorka badań zaliczyła wyeksponowanie szczegółowych kwestii związanych z ochroną środowiska (gospodarka odpadami, emisja dwutlenku węgla, odsiarczanie spalin). W dwóch przypadkach - za słabą stronę raportów - autorka uznała małe powiązanie danych niefinansowych $\mathrm{z}$ danymi finansowymi, zaś w jednym przypadku - zbyt dużą obszerność raportu.

Relacjonowane badania A. Piotrowskiej oczywiście nie są reprezentatywne, mają bowiem charakter case study, niemniej ich wyniki są wartościową ilustracją rozpatrywanych kwestii. Okazuje się, że już przed wprowadzeniem obligatoryjnych regulacji prawnych największe spółki giełdowe reprezentujące bardzo ważny sektor gospodarki kwestie odpowiedzialności społecznej traktowały - jak się wydaje - z należytą starannością i informacje na ten temat ujmowały w swoich raportach. Raporty te można było prezentować z dużo większą swobodą niż po wprowadzeniu obowiązujących aktualnie regulacji. Niemniej można wnosić, że wypełniły one swoje zadanie informowania interesariuszy o innych niż finansowe kwestie związane z odpowiedzialnością badanych spółek wobec społeczeństwa, a na pewno stanowiły dobrą bazę do sporządzania tego typu raportów w trybie obligatoryjnym .

Wnioski. Przepisy dyrektywy 2014/95/UE oraz przepisy jakie w ślad za nią prowadzono do ustawy o rachunkowości w 2016 r. są ważnym krokiem na drodze do standaryzacji raportów dotyczących kwestii odpowiedzialności społecznej przedsiębiorstw w Polsce. Przepisy te wypełniając istniejącą do tego momentu lukę regulacyjną, pozytywnie wpłynęły na jakość i przydatność informacji generowanych przez przedsiębiorstwa zobowiązane do ujawniania informacji sprawozdań niefinansowych, $w$ tym odnoszących się do obszarów: społecznego, środowiskowego i ładu korporacyjnego. Ich brak znacząco utrudniałby osiągnięcie porównywalności tego rodzaju raportów. Należy nadmienić, że przepisy te nie wprowadziły żadnych wiążących mandatów dla przedsiębiorstw zobowiązujących je do podejmowania działań w wymienionych obszarach. Nadal są one dobrowolne i pozostają w gestii zarządów przedsiębiorstw. Niemniej można wnosić, że już sam obowiązek ujawniania informacji na ten temat może prowadzić do lepszych wyników tychże działań.

Pozytywnym efektem obowiązku raportowania niefinansowego, w tym kwestii CSR może być to, że przedsiębiorstwa przygotowujące raporty potrafią lepiej zintegrować istotne informacje środowiskowe, społeczne i ładu korporacyjnego, co może prowadzić do identyfikacji istniejących problemów w tym zakresie, które nie były jeszcze rozpoznane. W rezultacie mogą w porę zostać podjęte działania pożądane lub działania przeciwdziałające zjawiskom, które zakłócają dobre funkcjonowanie przedsiębiorstwa.

Wśród słabości przepisów dotyczących raportowania kwestii niefinansowych z obszaru CSR należy zwrócić uwagę, iż ich obligatoryjne zastosowanie jest ograniczone do dużych korporacji oraz na to, że 
sprawozdawczość dotycząca tych kwestii nie osiągnęła jeszcze jakości rejestrowanej w sprawozdawczości finansowej. Słabość ta związana jest m.in. z problemem pomiaru szczegółowych zagadnień objętych tą sprawozdawczością. Trudno jest bowiem zmierzyć np. zadowolenie pracowników lub wpływ przedsiębiorstwa na jakość życia lokalnych społeczności.

Warto również zwrócić uwagę na problem poufności ujawnianych informacji wewnętrznych, które dotychczas nie były ujawniane. Jak się wydaje w trakcie sporządzania raportów z CSR przedsiębiorstwo musi porównać korzyści z ujawnienia takich informacji $\mathrm{z}$ wszelkimi zagrożeniami wynikającymi $\mathrm{z}$ tej procedury, która może skutkować np. osłabieniem jego pozycji konkurencyjnej.

Wyniki przedstawionych badań praktyki raportowania zagadnień społecznej odpowiedzialności potwierdzają, że większość przedsiębiorstw zobligowanych do ujawnień niefinansowych nałożony na nie obowiązek wypełnia. Kwestie CSR są ważną częścią tych ujawnień. Najpełniej przedstawione były kwestie pracownicze i środowiskowe; większość badanych jednostek przedstawiało zarówno założenia przyjętych polityk w tych zakresach jak i rezultatów ich prowadzenia. Największą trudność dla badanych przedsiębiorstw sprawiała prezentacja kwestii respektowania praw człowieka. Wśród standardów przydatnych do sporządzania raportów najbardziej popularne były wytyczne GRI. Satysfakcje mogą mieć również autorzy polskiego standardu SIN, który mimo, że został opracowany dopiero w $2017 \mathrm{r}$. wykorzystany był przez relatywnie wiele spółek. Badania potwierdziły również, że większość raportów nie była poddawana audytowi zewnętrznemu, co może świadczyć o braku przekonania menedżerów spółek o potrzebie takiej kontroli lub po prostu chęci ograniczenie kosztów wywiązania się z nałożonych obowiązków informacyjnych.

\section{Literatura}

1. Andrew Carnegie, The Gospel of Wealth And Other Timely Essays, Authorhouse , Book Jungle, 2009, s. 1336.

2. H. R. Bowen, Social Responsibilities of the Businessman, University of Iowa Press, Iowa City 2013.

3. J. Surdyk, CSR: więcej niż PR - dążenie do osiagnięcia dlugofalowej przewagi konkurencyjnej, [w:] Biznes, 1 tom, Zarzadzanie firma, część 1, Wydawnictwo Naukowe PWN, Warszawa 2007, s. 198.
4. Społeczna
odpowiedzialność
biznesu,
Departament
Pożytku
Publicznego,

http://www.pozytek.gov.pl/Spoleczna,odpowiedzialnosc,biznesu,464.html, dostęp 2 kwietnia 2015 r.

5. N.C Smith, Bounded goodness; marketing implications of Drucker on corporate responsibility, Journal of the Academy of Marketing Science, 2009, Vol.37. s. 73-84.

6. M. E. Porter, M. R. Kramer, The Competitive Advantage of Corporate Philanthropy, Harvard Business Review, December 2002, Vol. 80, s. 56-69.

7. Triple-bottom-line, The Economist. November 17, 2009, http://www.economist.com/node/14301663, dostęp 15 stycznia 2016.

8. Nasza wspólna przyszlość. Raport Światowej Komisji do Spraw Środowiska i Rozwoju, Państwowe Wydawnictwo Ekonomiczne, Warszawa 1991, s. 67.

9. Komunikat Komisji do Parlamentu Europejskiego, Rady, Europejskiego Komitetu Ekonomiczno-Spolecznego i Komitetu Regionów. Odnowiona strategia UE na lata 2011-2014 dotyczaca spolecznej odpowiedzialności przedsiębiorstw, Bruksela, dnia 25.10.2011 KOM(2011) 681. wersja ostateczna, s. 7.

10. Definicje $i$ standardy CSR, http://www.forbes.pl/artykuly/sekcje/baza-wiedzy-csr/definicje-i-standardycsr,3879,1, dostęp 2 czerwca 2016 r.

11. J.J. Asongu, The History of Corporate Social Responsibility, Journal of Business and Public Policy History of CSR Volume 1, Number 2 (Spring 2007), s. 9.

12. Obowiazkowe raportowanie $w$ zakresie CSR, https://www.obowiązki-informacyjne.pl/hotnews/obowiazkowe-raportowanie-w-zakresie-csr.html, dostęp 2 kwietnia 2015 r;

13. M. Zieliński, Korzyści z wdrożenia koncepcji CRS w zarządzaniu zasobami ludzkimi, Zeszyty Naukowe Politechniki Śląskiej, Seria: Organizacja i Zarządzania, nr 1921, 2014, s. 654-657.

14. Rowe, J.K. Corporate Social Responsibility as Business Strategy, [w;] Lipschutz, R. (red.) Globalization, Governmentality and Global Politics: Regulation for the Rest of Us? London 2005, Routledge, [za:] J.J. Asongu, op. cit. s. 14. 
15. Objectives of Financial Statements, Report of the Study Group on the Objectives of Financial Statements , American Institute of Certified Public Accountants, October 1973, s. 55, http://3197d6d14b5f19f2f4405e13d29c4c016cf96cbbfd197c579b45.r81.cf1.rackcdn.com/collection/papers/1970/1973_1001_TruebloodObjectives.p df, dostęp 1 lutego 2015 r.

16. Green Paper. Promoting a European framework for Corporate Social Responsibility, Commission of the European Communities, COM(2001) 366 final, Brussels.2001.

17. Corporate Social Responsibility: A business contribution to Sustainable Development, Commission of the European Communities, COM(2002) 347 final, Brussels 2002.

18. Dyrektywa Parlamentu Europejskiego $i$ Rady 2013/34/UE z dnia 26.06.2013 r. w sprawie rocznych sprawozdań finansowych, skonsolidowanych sprawozdań finansowych i powiazanych sprawozdań niektórych rodzajów jednostek, zmieniająca dyrektywę Parlamentu Europejskiego i Rady 2006/43/WE oraz uchylajaca dyrektywy Rady 78/660/EWG i 83/349/EWG, Dz. U. L 182 z 29.6. 2013 r.

19. Dyrektywa Parlamentu Europejskiego i Rady 2014/95/UE z dnia 22 października 2014 r. zmieniająca dyrektywe 2013/34/UE $w$ odniesieniu do ujawniania informacji niefinansowych i informacji dotyczacych różnorodności przez niektóre duże jednostki oraz grupy, Dziennik Urzędowy Unii Europejskiej, L 330/1.

20. Odnowiona strategia UE na lata 2011-2014 dotycząca społecznej odpowiedzialności przedsiębiorstw, Komunikat Komisji do Parlamentu Europejskiego, Rady, Europejskiego Komitetu Ekonomiczno-Społecznego i Komitetu Regionów, Komisja Europejska, Bruksela, dnia 25.10.2011,KOM(2011) 681.

21. EMAS (ang. Eco Management and Audit Scheme) to unijny instrument ochrony środowiska, funkcjonujący w oparciu o Rozporzadzenie Parlamentu Europejskiego i Rady (WE) nr 1221/2009 z 25 listopada 2009 r. w sprawie dobrowolnego udziału organizacji $w$ systemie ekozarzadzania $i$ audytu we Wspólnocie (EMAS), uchylajace rozporzadzenie (WE) nr 761/2001 oraz decyzje Komisji 2001/681/WE i 2006/193/WE.

22. Guidelines on non-financial reporting (methodology for reporting non-financial information) (2017/C 215/01), Official Journal of the European Union C 215/1, 5.07.2017.

23. Paris Agreement, United Nations 2015, https://unfccc.int/files/essential background/convention/application/pdf/english_paris agreement.pdf] [dostepp: 26.05.2017].

24. Ustawa o rachunkowości z dnia 29 września 1994 r., Dz. U. nr 121, poz. 591.

25. Krajowy Standard Rachunkowości nr 9 „Sprawozdanie z działalności”, Dz.Urz. Ministra Finansów z dnia 15.05.2014 r., poz. 17).

26. Standard Informacji Niefinansowych 2017, Fundacja Standardów Raportowania, https://standardy.org.pl/wppsndrd/wp-content/uploads/2017/10/SIN.pdf [dostęp: 13.03.2018 ].

27. T. Gabrusewicz, Rachunkowość odpowiedzialności społecznej $w$ ksztaltowaniu zasad nadzoru korporacyjnego, Wydawnictwo C.H. Beck, Warszawa 2010, s. 60.

28. P. Hąbek, Sprawozdawczość przedsiębiorstw w zakresie ich społecznej odpowiedzialności. Ocena jakości raportów CSR, CeDeWu, Warszawa 2015, s. 15.

29. Raportowanie rozszerzonych informacji niefinansowych za 2017 rok zgodnie z ustawa o rachunkowościpierwsze doświadczenia i dobre praktyki, Ministerstwo Finansów, Warszawa 2019.

30. J. Rubik, Raportowanie niefinansowe spółek Respect Index po zmianach, Studia Ekonomiczne. Zaszyty Naukowe Uniwersytetu Ekonomicznego w Katowicach, 2018, nr, 369, s. 211-220.

31. Raportowanie niefinansowe - przeglad rynku GPW, http://www.navigatorcapital.pl/raportowanieniefinansowe-przeglad-rynku/ dostęp 10.11.2019 r.

32. A. Piotrowska, Specyfika sprawozdawczości spółek giełdowych na przykładzie spółek sektora energetycznego, Gospodarka w Praktyce i Teorii, $2017 \mid \mathrm{nr}$ 4(49)| s. 69-82.

Стаття надійшла до редакції 24.01.2020 р. 